\title{
Communal Land Conflict and Food Security in Obudu Local Government Area of Cross River State, Nigeria
}

\author{
Francis Abul Uyang, Eucharia Nwabugo Nwagbara, Veronica Akwenabuaye Undelikwo, \\ Rosemary Ine Eneji \\ Department of Sociology, University of Calabar, Calabar, Nigeria \\ Email: eucharia n@yahoo.com
}

Received August 11 ${ }^{\text {th }}, 2013$; revised September $13^{\text {th }}, 2013$; accepted October $9^{\text {th }}, 2013$

\begin{abstract}
Copyright (C) 2013 Francis Abul Uyang et al. This is an open access article distributed under the Creative Commons Attribution License, which permits unrestricted use, distribution, and reproduction in any medium, pro-
\end{abstract} vided the original work is properly cited.

\begin{abstract}
This study examined the relationship between factors in communal land conflict and food security in Obudu Local Government Area of Cross River State, Nigeria. Two null hypotheses were formulated based on the selected independent variables of boundary dispute and scramble for other scarce economic resources like oil palm and other economic trees. Using the survey research design, data were collected from 400 randomly selected respondents. The data were statistically analysed using the chi-square $\left(\mathrm{X}^{2}\right)$ with probability set at the $5 \%$ level of significance. The results showed a significant relationship between boundary dispute and food security in Obudu on one hand and between scramble for scarce economic resources and food security on the other. We recommend among other things, that government at all levels should periodically mount enlightenment campaigns, seminars and symposia to sensitize the rural people on the devastating effect of communal land conflict. Also, conflict control mechanisms such as regular meetings and dialogue among neighbouring communities should be encouraged by community leaders to avert communal land conflict.
\end{abstract}

Keywords: Communal Land Conflicts; Boundary Dispute; Land; Food Security

\section{Introduction}

Land, an indispensible means of production, is at the core of most communal conflicts in Nigeria. Land also holds cultural significance for the people in most African communities. Studies on communal land conflict have not devoted much space on the significance of land and the role of cultural attachment to land in the prevalence of dispute over it. The significance of land among the Igbo of southeast Nigeria was graphically presented by V. C. Uchendu in 1965. According to Uchendu (1965: p. 22):

Land means many things to the Igbo. It is the domain of the earth-goddess, a burial place for the ancestors, a place to live on and make a living. Land is therefore the most important asset to the people. It is a source of security which is emotionally protected from alienation. It is believed that a people cannot have too much land and that no opportunity to acquire rights in land should be lost... There is no concept of "abandonment of land" or "no man's land" among the Igbo. Whether land is cultivated or not, it belongs to somebody... Land ultimately belongs to the lineage and cannot be alienated from it.

The scenario painted above by Uchendu of the Igbo people holds true of many parts of Nigeria and indeed the African continent. It explains the preponderance of conflict over land among neighboring communities. Part of the solution to the social malaise of communal land conflict therefore lies in the recognition of the cultural dimension to land disputes and their antecedents.
Indeed, communal land conflict has become a rampant component of social living in south eastern Nigeria. Instances of such conflicts involving communities in Cross River State and their neighbors in other states abound. Adadama Community in Abi Local Government Area of Cross River State and the Ameagu Community in Ikwo Local Government Area of Ebony State have been at war over a piece of farmland which has claimed several lives and injured several others. Also, several properties worth billions of naira were destroyed, including a police post situated on the boundary between the communities (http://www.paliarment.uk/document/posta274.pdf).

The age long communal land conflict between Nko community in Yakurr Local Government Area and Oyadama community in Obubra Local Government Area, both in Cross River State, over the ownership of a parcel of farmland further reinforces the worrying rate of communal land conflict among rural communities in Nigeria. Eventually, there was an outbreak of communal land conflict between Nko and Oyadama communities in April 2013, which led to destructions of farms, loss of lives and several injuries, including destruction of properties worth millions of naira. Communal land conflicts wherever they occurred have had devastating effects on food security (http://www.Parliament.uk/document/Postn274.pdf).

A major cause of communal land conflicts in Nigeria is boundary dispute since the boundary area is becoming a very critical factor for agricultural production (Otite \& Albert, 2001; Dunmoye, 2003; Ogwuda, 2010; Okpiliya, Ekong, \& Eni, 2013). Goshit (2004) observed that communal land conflicts fuelled by increasing boundary disputes were due to population pressure 
and these were compounding the problem of food insecurity in Nigeria. Izugbara, Ugal, \& Ukwayi (2003) and Olayemi (1996) noted that competition for access to and control of socially valued environmental and economic goods such as land, water resources, and economic trees was responsible for many of the communal clashes in Nigeria. Studies on the effect of communal land conflict on food productivity in developing countries (Ageaoili, Perez, \& Rosegrant, 1995; Sambe, Avanger, \& Alakali, 2013; Okpiliya, Ekong, \& Eni, 2013) showed that several boundary disputes resulting to communal conflict, especially in Africa have impeded food productivity. Arising from an empirical study which found a correlation between communal violence and food security in Africa, Sambe, Avanger, \& Alakali, (2013: p. 46) painted the following scenario:

Communal conflicts are enemies of food security. There is a well-established correlation between the exposure of countries to communal conflicts and the deterioration and long term stagnation of their food security. The conflict disrupts food production through physical destruction and plundering of crops and livestock, harvest and food reserves. Communal conflicts also prevent and discourage farming and also interrupt the lives of transportation through which food exchanges and even humanitarians relief takes place.

Mustapha (2010) observed that the boundary dispute between Aguleri and Umuleri communities in Anambra State caused indigenes to become refugees in neighboring towns. Recently, the devastating effect of the boundary dispute between the Moon people of Kwande Local Government Area of Benue state and the Kashimbila community in Takun Local Government Area of Taraba state was brought to the realm of political discussion (Salem, 2013).

According to Chizea \& Iyare (2006), scramble for scarce economic resources exacerbate conflict, undermine the rule of law and spawn a culture of violence and impunity, the conesquence of which is a threat to food security. Earlier studies by scholars have attested to the relationship between scramble for scarce economic resources and communal conflicts (Onwudiwe, 2004; Irobi, 2005). In a study of the relationship between scramble for scarce economic resources and food security, Hazen \& Horner (2007) found that scramble for scarce resources was on the increase in Nigeria. Essentially, their study revealed the scramble engendered communal land conflict, which forced many people to flee their homes and villages. Thus, they concluded that scramble for scarce economic resources was likely to increase the problem of food insecurity in Nigeria. Food security was negatively affected by scramble for scarce economic resources in other parts of Africa (Migot-Adholla, Peter, Benoit, \& Frank, 1991; Carter, Weibe, \& Blarel, 1994).

Land, as unit for agricultural production provides the needed fulcrum upon which a sustainable development would blossom. Agricultural production till date remains the mainstay of the Nigeria economy, despite the exploration and exploitation of crude oil in the country for more than five decades. It is the main source of food for most of the population. Agriculture provides the means of livelihood for over 70 per cent of the population, a major source of raw materials for the agro-allied industries and a potent source of the much needed foreign exchange. However, over the years, the agricultural sector has witnessed a tremendous decline due partly to scramble for scarce economic resources leading to communal land conflicts with adverse effects on food security (World Bank, 1988). These conflicts have been a dominant factor of food insecurity in most rural communities in the developing countries (Drezen \& Sen, 1989).

Also, the exponential increase in human population without a corresponding increase in land, coupled with devastating natural disasters, worsen the problem of scramble for land and other scarce economic resources. According to Kennedy-Echetebu, Chinweze, \& Abiola-Oloke (2011), sub-Saharan Africa which is already under pressure from population growth, famine, drought and conflict, increases in biofuel production and concomitant land grabs can only contribute to weakening food security and keeping achievement of the Millennium Development Goals far beyond reach. Again, a report by the Norwegian Refugee Council (2012) found that in both south-eastern Liberia and western Côte d'Ivoire, land disputes remain a major obstacle to building sustainable peace and a potential threat to continued development and food security. Disputes over land are common in all communities visited on both sides of the border. In this study, we examined the relationship between factors in communal land conflict and food security in Obudu Local Government Area of Cross River State, Nigeria.

\section{Methodology}

\section{Study Area}

The study area was Obudu Local Government Area (LGA) of Cross River State, Nigeria. It is one of the 18 LGAs that make up the State. The location of Obudu $\left(6^{\circ} 20^{\prime \prime}-6^{\circ} 40^{\prime \prime N} ; 8^{\circ} 4^{\prime \prime}\right.$ $-9^{\circ} 0^{\prime E} \mathrm{E}$ ) and its climatic conditions are conducive for the cultivation of a large variety of agricultural products. The soil is loamy sand mixed with volcanic ash. The LGA covers an area of 379,164 square kilometres and to the west, it shares a boundary with Bekwarra/Ogoja local Government Areas, to the east with Obanliku Local Government Area, to the South with Boki Local Government Area (all in Cross River State) and to the North with Benue State. Obudu Local Government Area is made up of five indigenous ethnic communities of Bette, Alege, Ukpe, Ubang and Utugwang. Obudu enjoys the influence of the North easterly wind during the dry season and south westerly wind during the wet season with annual mean rainfall of about 1300 - 2000 millimetres. The main vegetation characteristic of the area is guinea savannah. The inhabitants of Obudu are mostly farmers but the frequent occurrence of communal land conflict among communities in the area adversely affects farming activities. The population of Obudu, according to the 2006 census figures was 161,457 and this figure was projected to increase to 322,914 by 2040 (FRN, 2009). Ironically, while the annual increase in population of the area is about 3 percent, land, the vital resource at the heart of most communal conflicts, remains static or even depreciates.

\section{Questionnaire and Data Collection}

This was a survey study that relied on the questionnaire as the major instrument of data collection. The questionnaire was structured with some open- and close-ended questions. The close-ended questions were carefully crafted to elicit information amenable to easy collation and test of hypotheses. The open-ended questions though few were put in place to enable respondents express themselves freely on the phenomenon of communal land conflict and increasing rate of food insecurity 
in Nigeria with focus on Obudu Local Government Area. The essence was to enrich the description and narration of the phenomenon under investigation; limiting respondents to only closeended questions may hinder information which otherwise would be obtained from open-ended questions.

The hypotheses for the study were as follows:

- There is no significant relationship between boundary dispute and food security in Obudu.

- There is no significant relationship between scramble for scarce economic resource and food security in Obudu.

Obudu Local government Area is made up of 10 political wards and each of these constituted a cluster in the study. The 10 clusters were: Obudu urban I ward, Obudu urban II ward, Begiading ward, Ipong ward, Agiaba/Begiaka ward, Alege/ Ubang ward, Ukpe ward, Utugwang South ward, Utugwang central ward and Utugwang North ward. Simple random sampling technique was used to select two (2) communities from each cluster. Through the use of hat and draw method of simple random sampling, 20 communities were selected from the 10 clusters.

From each cluster, respondents were selected through the systematic random sampling procedure. This involved the enumeration of the living houses in each sampled community (in the ward) into even and odd numbers. Only even numbered houses were systematically sampled in each enumerated cluster and any adult found in each house was given a questionnaire to fill. This procedure was applied throughout the 10 clusters of the study area. Forty (40) respondents (that is 20 respondents per community) were selected from each cluster. The systematic random sampling procedure was applied throughout the twenty (20) communities that were selected in the study and a total of four hundred (400) respondents were involved in the study. In addition to the primary data, secondary sources such as library research and internet resources were utilized.

\section{Data Analysis Procedure}

To test the hypotheses in this study, the chi-square $\left(\mathrm{X}^{2}\right)$ distribution was used to explore the relationship between two variables. The variables in the study were boundary dispute, scramble for scarce economic resources and communal land conflict. While boundary dispute and scramble for scarce economic resources were the independent variables, communal land conflict was the dependent variable. The formula for calculating the chisquare distribution is

$$
X^{2}=\sum\left(\frac{O-E}{E}\right)^{2}
$$

where: $\mathrm{O}=$ Observed value of distribution

$\mathrm{E}=$ Expected value of distribution

$\sum=$ Summation

$\mathrm{X}^{2}=$ Chi-Square

As a general rule, if the calculated value is greater than the tabulated or critical value, then there is significant relationship and therefore, the alternate hypothesis is accepted and if the calculate value is less than the tabulated or critical value, then there is no significant relationship and therefore, the null hypothesis is accepted.

\section{Results}

The data in Table 1 show that 130 respondents representing
Table 1.

Distribution of respondents' responses on boundary dispute and food security in Obudu.

\begin{tabular}{lcc}
\hline \multicolumn{1}{c}{ Response option } & No. of respondents & Percentage \\
\hline Strongly Agree & 130 & 32.50 \\
Agree & 215 & 53.75 \\
Disagree & 35 & 8.75 \\
Strongly Disagree & 20 & 5 \\
Total & 400 & 100 \\
\hline
\end{tabular}

Source: Fieldwork, 2012.

32.50 per cent strongly agreed that boundary dispute affects food security in Obudu, 215 respondents (53.75 per cent) agreed, 35 respondents ( 8.75 per cent) disagreed while 20 respondents ( 5 per cent) strongly disagreed. Majority of the respondents (more than 86 per cent) agreed with the notion that boundary dispute affects food security in Obudu.

Table 2 shows that 231 respondents representing (57.5 per cent) strongly agreed that scramble for scarce economic resource can lead to communal land conflict, 149 respondents (37. 25 per cent) agreed, 12 respondents ( 3 per cent) disagreed while 8 respondents ( 2 per cent) strongly disagreed. Thus the overwhelming majority of the respondents (about 95 percent) agreed that the scramble for scarce economic resources leads to communal land conflict in Obudu L. G. A.

Results of chi-square analysis are shown in Table 3 . The calculated $\mathrm{X}^{2}$ showed a significant relationship between boundary dispute and food security. We therefore accepted the alternate hypothesis and concluded that boundary dispute would adversely food security in the area.

Chi square analysis of the relationship between scramble for scarce economic resources and communal land conflict (Table 4) shows that scramble for scarce economic resources actually leads to communal land conflicts and hence, a threat to food security in the area. Thus, we rejected the null hypothesis in favour of the alternate hypothesis that there is a significant relationship between scramble for scarce economic resources and food security in Obudu LGA.

\section{Discussion}

The overall findings showed that boundary dispute is a significant cause of food security problem in the study area (Table 3). This observation is consistent with those of Dunmoye (2003) who also attributed the major cause of communal land conflict to boundary dispute. Communal conflict has a very significant influence on food security. For instance, the on-going famine in war-prone Somalia has led to much speculation about the link between violent conflict and food insecurity. Similarly, some commentators have also connected the recent political revolutions in Egypt and Tunisia to record high food prices (Notaras, 2011). Emphasizing on the trajectory between the social phenomena of communal conflicts and food security, the Food and Agricultural Organization (FAO) (2002: p. 1) observes:

Most conflicts, and especially the internal conflicts that have now become the dominant model of mass violence, mainly affect rural areas and their populations. They disrupt food production through physical destruction and plundering of crops and livestock, harvests and food re- 
Table 2.

Distribution of respondents' responses on the relationship between scramble for scarce economic resources (e.g. palm trees) and communal land conflict.

\begin{tabular}{lcc}
\hline \multicolumn{1}{c}{ Response option } & No. of respondents & Percentage \\
\hline Strongly Agree & 231 & 57.75 \\
Agree & 149 & 37.25 \\
Disagree & 12 & 3 \\
Strongly Disagree & 8 & 2 \\
Total & 400 & 100 \\
\hline
\end{tabular}

Source: Fieldwork, 2012.

Table 3.

Chi-square $\left(\mathrm{X}^{2}\right)$ analysis of the relationship between boundary dispute and food security in Obudu.

\begin{tabular}{ccccccc}
\hline \multicolumn{7}{c}{ Responses } \\
\hline Variables & SA & A & D & SD & Total & Value \\
\hline $\begin{array}{c}\text { Boundary } \\
\text { Dispute }\end{array}$ & $70(72.8)^{\dagger}$ & $145(120.4)$ & $5(19.6)$ & $4(11.2)$ & 224 & $46.91^{*}$ \\
$\begin{array}{c}\text { Food Security } \\
\text { in Obudu } \\
\text { Total }\end{array}$ & $60(57.2)$ & $70(94.6)$ & $30(15.4)$ & $16(8.8)$ & 176 & \\
\hline
\end{tabular}

Source: Fieldwork, 2012; ${ }^{\dagger}$ Values in bracket represent the expected values: "significant at $\mathrm{P}<.05 ; \mathrm{n}=3$.

Table 4.

Chi-square $\left(\mathrm{X}^{2}\right)$ analysis of the relationship between scramble for scarce economic resource and food security in Obudu.

\begin{tabular}{|c|c|c|c|c|c|c|}
\hline & \multicolumn{4}{|c|}{ Responses } & \multicolumn{2}{|c|}{$\mathrm{X}^{2}$} \\
\hline Variables & SA & A & $\mathrm{D}$ & SD & Total & value \\
\hline $\begin{array}{l}\text { Scramble for } \\
\text { scarce }\end{array}$ & $\begin{array}{c}152 \\
(120.4)^{+}\end{array}$ & $\begin{array}{c}53 \\
(81.2)\end{array}$ & $\begin{array}{c}14 \\
(15.12)\end{array}$ & $5(7.28)$ & 224 & \\
\hline \multicolumn{7}{|l|}{$\begin{array}{l}\text { Economic } \\
\text { resource }\end{array}$} \\
\hline & & & & & & $42.40^{*}$ \\
\hline $\begin{array}{l}\text { Food Security } \\
\text { in Obudu }\end{array}$ & $63(94.6)$ & $\begin{array}{c}92 \\
(63.8)\end{array}$ & $\begin{array}{c}13 \\
(11.88)\end{array}$ & $8(5.72)$ & 176 & \\
\hline Total & 215 & 145 & 27 & 13 & 400 & \\
\hline
\end{tabular}

Source: Fieldwork, 2012; ${ }^{+}$Values in bracket represent the expected values: *significant at $\mathrm{P}<.05 ; \mathrm{n}=3$.

serves; they prevent and discourage farming; they interrupt the lines of transportation through which food exchanges, and even humanitarian relief, they destroy farm capital, conscript young and able-bodied males, taking them away from farm work and suppress income earning occupations.

Since the boundary area is a very crucial factor for agricultural production, any dispute there is a dangerous signal for food security.

The result in Table 4 shows that scramble for scarce economic resources leads to communal land conflict which negatively affects food security based on the calculated $\mathrm{X}^{2}$ value. According to Chizea \& Iyare (2006), the scramble for scarce economic resources exacerbate communal land conflict with arms and other dangerous weapons freely used, leading to massive killings, displacement of people and destruction of farms worth millions of naira. In an earlier study on scramble for scarce economic resources and food security Hazen and Horner (2007) found that the scramble was on the increase in Nigeria, a situation which often propels communal land conflict, during which many people are forced to flee their homes and villages, thereby exacerbating the problem of food insecurity in the country.

\section{Conclusion and Recommendations}

Frequent communal land conflicts in contemporary Nigeria have exacerbated food insecurity in the society. Apart from the people killed and properties lost, there is massive crop loss, loss of stored food and consequent increase in food prices and famine. Communal land conflicts cause food emergencies and able bodied men that would have worked on the farm to migrate to non-conflict areas. Communal land conflict interferes with agricultural production, people desert the area and agricultural activities are halted. The economic and social cost of communal land conflict is not only deep but also persists, even for years after the end of the physical conflict.

Communal land conflict is an endemic cankerworm that has continued to eat deep into the very essence of social living anywhere it occurred and so calls for proper methodical approach which takes into cognizance the cultural dimension toward its resolution. The comprehension of the furore over land and scarce economic resources among and between communities is better appreciated when we situate cultural significance of land to the people. Attempts to address the social vice of land conflicts should also consider the social reality of population explosion. Based on the findings, the following recommendations are made:

1) Government should vigorously pursue policies that would reduce or eliminate communal land conflict and improve food security.

2) Conflicts are inevitable in any society but the problem is the management. Conflict management and peace-building mechanisms such as regular meetings and dialogue between neighboring communities should be encouraged by community and renowned political leaders to avert communal land conflict.

3) Cultural dimension of land should be considered by any group saddled with the responsibility of mediating between communities in conflict over parcels of land.

4) Government should act timely when there is communal land conflict in any part of the federation. The untimely intervention by government in past cases of communal land conflicts has cost many lives and destruction of farms worth millions of naira. Security agents in the country should act fast and decisively.

\section{REFERENCES}

Ageaoili, M. P., \& Rosegrant, W. (1995). Impact of resources degradation on global food balance. Paper presented at workshop on Land Degradation in the Developing World: Implication for Food, Agriculture and the Environment to the Year 2020. Anapolis.

Carter, M. R., Wiebe, K. D., \& Blarel, B. (1994). Tenure security for whom? Differential effects of land policy in Kenya. In W. John Bruce, \& S. E. Migot-Adholla (Eds.), Searching for land tenure security in Africa. Dubuque Kendall/Hunt Publishers.

Chizea, B., \& Lyare, T. (2006). Nigeria's raging ethnic conflicts: The role of small arms and Private Military Companies (PMCS). The Constitution: A Journal of Constitutional Development, 6, 71-97. 


\section{F. A. UYANG ET AL.}

Communal clash in Cross River.

http://www.parliament.uk/documents/postn274.pdf

Communities at war over land disputes.

http://www.parliament.uk/documents/postn274.pdf

Drezen, J., \& Sen, A. (1989). Hunger and public action. Oxford: Clerendo Press.

Dunmoye, R. A. (2003). General survey of conflicts in the Middle Belt Zones. Journal of Centre for Peace Research and Conflict, Abuja: National War College.

FAO (10-13 June, 2002). Food, security, justice and peace. http://www.fao.org/worldfoodsummit/msd/y6808e.htm

Federal Republic of Nigeria (FRN) (2009). Legal notice on publication of 2006 census final results. Official Gazette, Abuja: Federal Government Printer.

Goshit, Z. D. (2004). Food security and entrenchment of durable democracy in Nigeria. In: M. O. Maduagwu, \& A. S. Mohammed (Eds.), Challenges and prospects of democratization in Nigeria, Fulbright Alumni Association of Nigeria. Nsukka: Multi-Educational Services Trust.

Hazen, J. M., \& Horner, J. (2007). Small arms, armed violence, and insecurity in Nigeria: The Niger Delta in perspective. Geneva: Small Arms Survey.

Irobi, E. G. (2005). Ethnic conflict management in Africa: A comparative case study of Nigeria and South Africa.

http://www.beyondintractability.org/casestudy/irobi-ethnic

Izugbara, C. O., Ugal, G. A., \& Ukwayi, J. K. (2003). Indigenous Knowledge and communal conflict resolution: Evidence from Nigeria. Indilinga-African Journal of Indigenous Knowledge System, 2, 1-14.

Jideani, C., Kennedy-Echetebu, C., Chinweze, C., \& Abiola-Oloke, G. (2011). Biofuels and food security: Green economy in sub-Saharan Africa.

http://www.unrisd.org/80256B3C005BE6B5/search/D3DDEAB7AC 94EDAB C125794B00486826?OpenDocument

Migot-Adholla, S., Peter, H., Benoit, B., \& Frank, P. (1991). Indige- nous land rights system in sub-Saharan Africa: A constraint on productivity? World Bank Economic Review, 5, 155-175. http://dx.doi.org/10.1093/wber/5.1.155

Mustafa, A. (2010). Nigeria: Land disputes-Share community raises fresh alarm. http://allafrica-com/stones/201003240522.htmL

Norwegian Refugee Council Report (2012). Land conflict and food security in the Liberian-Ivoirian Border Region. http://www.fao.org/worldfoodsummit/msd/y6808e.htm World Food Summit Five Year Later 10-13 June, 2002

Notaras, M. (2011). Food insecurity and the conflict trap. http://ourworld.unu.edu/en/food-insecurity-and-the-conflict-trap/

Ogwuda, A. (2010). Nigeria: Lives lost as village flee over 50 years old land dispute. http://www.allafrica.comstones/20070609002.html

Okpiliya, F. I., Ekong, A. E., \& Eni, I. (2013). Wetland ecosystem conflict: Implication for agricultural productivity and food Security in Mbiabo, Odukpani, Cross River State, Nigeria. Mediterranean Journal of Social Sciences, 4, pp. 55-61.

Olayemi, J. K. (1996). Food security in Nigeria. Ibadan: Development Policy Centre Report.

Onwudiwe, E. (2004). Communal violence and the future of Nigeria. http://www.worlddialogue.org/content.php?id=321

Otite, O., \& Albert, I. O. (2001). Community conflicts in Nigeria: Management, resolution and transformation. Ibadan: Spectrum Books.

Salem, T. (2013). Reps intervene in Benue-Taraba boundary dispute. $\mathrm{http} / /$ nationalmirroronline.net/new/reps-intervene-in-benue-taraba-b oundary-dispute/

Sambe, N., Avanger, M. Y., \& Alakali. T. T. (2013). Communal violence and food security in Africa. IOSR Journal of Humanities and Social Science (IOSR-JHSS), 9, 43-47.

Uchendu, V. C. (1965). The igbo of Southeast Nigeria. New York: Holt, Rinehart and Winston.

World Bank (1988). Human development report. Washington DC: World Bank Publication. 